Ind. Health, 1968, 6, 120.

\title{
ON PERFORMANCE OF A DIFFUSION CELL FOR PREPA- RATION OF AIR FLOW CONTAINING LOW CONCENTRATION OF ORGANIC VAPOR
}

\author{
Heihachiro ARITO and Reisuke SODA \\ National Institute of Industrial Health, Kizuki-Sumiyoshi, Kawasaki
}

(Received August 8, 1968)

\begin{abstract}
A simple diffusion cell was examined on its applicability for routine use as a generator of air flow containing low concentration of organic vapor. Both the fluctuation of concentration of vapor in the air flow and the ratio of the time-averaged concentration to the calculated one were observed by gas chromatographic technique at short time intervals of sampling for two hours or more. Much fluctuation of concentration in the stationary state of operation was noticed beyond certain ranges of the values of the operational conditions and structural factors of the cell. An attempt to reduce such fluctuation was made and the buffer flasks proved to absorb it effectively. The time-averaged concentrations from $0.4 \mathrm{ppm}$ to $82 \mathrm{ppm}$ were in good agreement with the calculated ones.
\end{abstract}

A device for preparation of air flow containing low and constant concentration of vapor has been required in studies of industrial hygiene and air pollution. Various types of devices have been reported. ${ }^{1 \sim 3)}$ Among those devices there has been a diffusion cell ${ }^{49}$ ) with which a continuous flow of low concentration mixture of organic vapor and air was prepared by using the diffusion process of the vapor through a cylindrical tube from a reservoir containing some liquid. The diffusion cell can be applied for almost all kinds of organic compounds in liquid state at normal temperature and pressure. In addition, the concentration is predicted from the flow rate of diluent air and the calculated rate of diffusion of the vapor through a tube of known size. The calculated concentrations were in good agreement with the observed ones in a certain range of the concentration prepared. ${ }^{4,6)}$

In those reports weight or volume of the liquid before and after operation of the cell was measured, and used together with the flow rate of diluent air, to determine the concentration. Such determination method of concentration showed neither a change in concentration in intial stage nor a fluctuation in concentration in stationary state, but only the time-averaged concentration over the running period of the cell. It is important, however, to check the fluctuation in concentration of vapor in the air flow prepared with the diffusion cell, because much fluctuation limits the applicability of the cell to the practical use.

The present work is aimed at investigating the fluctuation of concentration in the stationary state and the ratio of the time-averaged concentration in the stationary state to the calculated one. Furthermore, an attempt is made to reduce the 


\section{PERFORMANCE OF DIFFUSION CELL}

fluctuation by setting up three buffer flasks. The concentration of the vapor is observed by gas chromatographic technique at short time intervals.

\section{EXPERIMENTALS}

\section{(1) Diffusion cell}

The diffusion cell which was originally described by McKelvey and Hoelscher ${ }^{4}$ ) was modified and used. Performance of the cell was examined by preparing air flow containing benzene vapor with the cell. The cell consisted of a set of three parts which were made of glass: a mixing flask, a cylindrical tube and a conical reservoir. An elliptical flask of $90 \mathrm{ml}$ and a round one of $500 \mathrm{ml}$ were used as the mixing flask. The cylindrical tube was used as a diffusion tube. Nine diffusion tubes of different sizes were used. They were from $10.2 \mathrm{~cm}$ to $20.5 \mathrm{~cm}$ in length and from $0.7 \mathrm{~mm}$ to $9.9 \mathrm{~mm}$ in inner diameter. Reservoirs with volumes of $50 \mathrm{ml}$ and $125 \mathrm{ml}$ were used. The cell which was assembled with each of the three parts, was connected with a triple U-shaped glass tube of $1.6 \mathrm{~m}$ in length and $1.5 \mathrm{~cm}$ in outer diameter, which served for conditioning temperature of the air to be introduced into the mixing flask. Whole assembly was dipped into the water bath in which temperature was kept constant with an electric thermostat. The air flow containing the vapor was led to the gas sampling part through either the pass with three buffer flasks or that without them as described in Figs. 1-B and $1-\mathrm{A}$, respectively.

\section{(2) Gas chromatographic determination of vapor concentration}

A Perkin-Elmer Model 800 type gas chromatograph equipped with a hydrogen flame ionization detector was used to determine the concentration of benzene vapor. A Hitachi QPD 53 multi-range recorder was used. Nitrogen was used as carrier gas at the flow rate of $30 \mathrm{ml} / \mathrm{min}$. Porapak Q of $150-200$ mesh which was packed into a stainless steel column of 3 feet in length and $1 / 8$ inch in outer diameter was used to separate benzene vapor from the other components of air. A gas sampling valve was installed on the gas chramatograph. Precisely reproducible volume of the vapor-air mixture was intermittently introduced into the separation column through a gas sampling tube which was fitted on the gas sampling valve. Retention time of benzene peak on the gas chromatogram was about $6 \mathrm{~min}$ at the column temperature of $190^{\circ} \mathrm{C}$. Sensitivity of the gas chromatographic detector to benzene was calibrated by injecting a standard solution of benzene in $n$-heptane into the gas chromatograph with a Hamilton microsyringe of $1 \mu$ l under the same conditions as those for the vapor-air mixture.

\section{(3) Sampling device of the air flow}

Fig. 1 shows the flow diagram of the device and the sampling system of the vapor-air mixture. In order to introduce the fixed volume of the mixture into the gas sampling tube without interrupting the flow during sampling procedure, a by- 
A
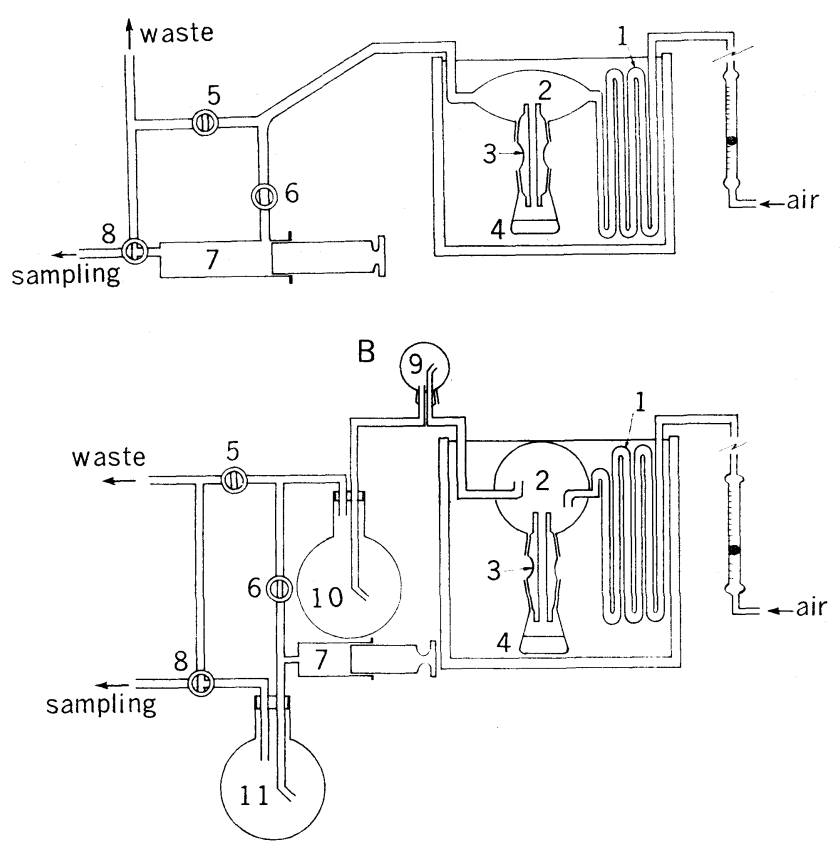

Fig. 1. Schematic diagrams of a diffusion cell and flow system.

A : without buffer flask, B: with the buffer flasks.

1 , tube for conditioning temperature of air. 2, mixing flask. 3, diffusion tube. 4, reservoir for organic liquid. 5, two-way stop cock B.

6, two-way stop cock A. 7, syringe. 8 , three-way stop cock.

9,10 and 11 , buffer flasks of $0.5,3.0$ and 3.0 liters, respectively.

pass was set up from the outlet of the mixing flask to the sampling part. The flow was usually kept to pass through a two-way stop cock A, a cylinder of the syringe of $120 \mathrm{ml}$ and a three-way stop cock in series to the outlet for waste, while a two-way stop cock B remained closed. Sampling of the mixture was carried out by a procedure in following order: 1. Open the two-way cock B, 2 . Shut the two-way cock A, 3. Turn the outlet of the three-way cock to the inlet of the gas sampling valve and 4. Push the plunger of the syringe. The sampling tube was filled with its equivalent volume of the mixture by the operation 4 . After the mixture was sampled, the flow line was changed back to the original one by reversing the above sampling procedure. Interval of the sampling was. adjusted to 7 or $8 \mathrm{~min}$ because of the retention time of benzene.

\section{(4) Materials}

Air was supplied from a gas cylinder through one step of the pressure reducing valve and was used without any filtration. Benzene of the special grade reagent was confirmed to be free from any impurity by gas chromatography. n-Hep- 


\section{PERFORMANCE OF DIFFUSION CELL}

tane was used as the solvent of the standard solution of benzene. No peak corresponding to impurities of n-heptane was found in the neighborhood of the peak of benzene in the chromatogram.

\section{(5) Calculation}

As a measure of fluctuation of the concentration of vapor in the air flow, the coefficient of variation was employed. It was obtained by deviding the standard deviation by the arithmetic mean value and was expressed as $\%$. The standard deviation and the mean value were calculated with more than ten successive gas chromatographic peak heights of benzene which were obtained in the stationary state.

The concentration was expressed by the unit of ppm in volume. The calculated concentration was obtained from the diffusion rate of vapor through a cylindrical tube and the flow rate of air as follows.

$$
\begin{aligned}
& \mathrm{r}=\frac{\mathrm{DPMA}}{\mathrm{RTL}} \ln \frac{\mathrm{P}}{\mathrm{P}-\mathrm{p}} \\
& \mathrm{D}=\mathrm{D}_{\circ}\left(\frac{\mathrm{T}}{\mathrm{T}_{\circ}}\right)^{m}\left(\frac{\mathrm{P}_{\circ}}{\mathrm{P}}\right) \\
& \mathrm{C}=\frac{\mathrm{r}}{\mathrm{F}} \times 10^{6}
\end{aligned}
$$

where, $\mathrm{C}$ : concentration in $\mathrm{ppm}, \mathrm{F}$ : flow rate of air in $\mathrm{ml} / \mathrm{min}, \mathrm{r}$ : diffusion rate in $\mathrm{ml} / \mathrm{min}, \mathrm{D}$ and $\mathrm{D}_{\circ}{ }^{10)}$ : diffusion coefficient at temperature $\mathrm{T}$ and pressure $\mathrm{P}$ and at $0^{\circ} \mathrm{C}$ and 1 atm., respectively, $\mathrm{M}$ and $\mathrm{p}$ : molecular weight and vapor pressure of the liquid, respectively, $\mathrm{R}$ : gas constant, $\mathrm{A}$ and $\mathrm{L}$ : cross sectional area and length of the diffusion tube, respectively, and $m=2$ for benzene. ${ }^{10}$ )

\section{Results and Discussion}

The equations 1 and 2 show that the concentration of the vapor-air mixture which is prepared with the diffusion cell can be changed by four factors: the flow rate of diluent air, temperature (vapor pressure of the liquid), inner diameter and length of the cylindrical diffusion tube. The effect of each factor on fluctuation of concentration and on coincidence of the time-averaged concentration with the calculated one was examined by preparing benzene-air mixture. The fluctuation was expressed as the coefficient of variation of concentration. The time-averaged concentration was obtained with the mean value of peak heights which were observed for two hours or more. Both the fluctuation and the coincidence were obtained in the stationary state. In examining each factor, the other factors were kept constant.

Table 1 shows the effect of flow rate of air on the coefficient of variation of concentration and on the coincidence of the time-averaged concentration with the calculated one. Only the flow rate of air was changed from $500 \mathrm{ml} / \mathrm{min}$ to 1,800 $\mathrm{ml} / \mathrm{min}$ for two different inner diameters of the diffution tubes. When the inner 


\section{H. ARITO AND R. SODA}

Table 1. Relation between the flow rate of air and the coefficient of variation of concentration and the ratio of the time-averaged concentration to the calculated one.

\begin{tabular}{|c|c|c|c|c|c|c|}
\hline \multirow{2}{*}{$\begin{array}{l}\text { Size of } \\
\text { diffusion tube }\end{array}$} & \multicolumn{3}{|c|}{$2.1 \mathrm{~mm}$ (i.d.), $162 \mathrm{~mm}$ (length) } & \multicolumn{3}{|c|}{$9.9 \mathrm{~mm}$ (i.d.), $161 \mathrm{~mm}$ (length) } \\
\hline & $\begin{array}{l}\text { Calculated } \\
\text { concentration } \\
(\mathrm{ppm})\end{array}$ & $\begin{array}{l}\text { Coefficient } \\
\text { of variation } \\
(\%)\end{array}$ & $\begin{array}{l}\text { Ratio } \\
\mathrm{C}_{\mathrm{obs}} / \mathrm{C}_{\mathrm{calc}}\end{array}$ & $\begin{array}{l}\text { Calculated } \\
\text { concentration } \\
(\mathrm{ppm})\end{array}$ & $\begin{array}{l}\text { Coefficient } \\
\text { of variation } \\
(\%)\end{array}$ & $\begin{array}{l}\text { Ratio } \\
\mathrm{C}_{\text {obs }} / \mathrm{C}_{\text {cale }}\end{array}$ \\
\hline 520 & 3.6 & 3 (2) & 1.0 & 82 & 1 & 0.9 \\
\hline 720 & - & $-(-)$ & - & 59 & 1 & 0.9 \\
\hline 920 & 2.0 & 4 (1) & 1.0 & 46 & 1 & 0.9 \\
\hline 1,350 & 1.4 & $6(4)$ & 1.1 & 32 & 0 & 0.9 \\
\hline 1,800 & 1.0 & 10 (2) & 1. 1 & 23 & 1 & 0.9 \\
\hline
\end{tabular}

Numbers in parenthesis were obtained by passing the flows through the buffer flasks after a round mixing flask and the others without the buffer flask after an elliptical mixing flask.

$\mathrm{C}_{\mathrm{obs}}$ : The time-averaged concentration observed in the stationary state.

Temperature of water bath: $30^{\circ} \mathrm{C}$

diameter of the tube was of $2.1 \mathrm{~mm}$ and the flows were not passed through the buffer flasks, the coefficients of variation increased with increasing flow rate of air. The time-averaged concentrations, however, were in good agreement with the calculated ones in this instance. With the broader inner diameter of $9.9 \mathrm{~mm}$ and without the buffer flasks, too, the time-averaged concentrations were in good agreement with the calculated ones and their coefficients of variation were so small that the dependence of the flow rate on the coefficients was not recognized as was in the inner diameter of $2 \mathrm{~mm}$.

Table 2 shows the effect of temperature on the coefficient of variation of concentration and on the coincidence of the time-averaged concentration with the

Table 2. Relation between temperature of water bath and the coefficient of variation of concentration and the ratio of the time-averaged concentration to the calculated one.

\begin{tabular}{c|c|c|cc|c}
\hline $\begin{array}{l}\text { Temperature } \\
\text { of water bath } \\
\left({ }^{\circ} \mathrm{C}\right)\end{array}$ & $\begin{array}{l}\text { Room } \\
\text { temperature } \\
\left({ }^{\circ} \mathrm{C}\right)\end{array}$ & $\begin{array}{l}\text { Calculated } \\
\text { concentration } \\
(\mathrm{ppm})\end{array}$ & $\begin{array}{l}\text { Coefficient } \\
\text { of variation } \\
(\%)\end{array}$ & $\begin{array}{c}\text { Ratio } \\
\mathrm{C}_{\mathrm{obs}} / \mathrm{C}_{\mathrm{ca} \cdot \mathrm{c}}\end{array}$ \\
\hline 5 & 17 & 0.8 & 6 & $(-)$ & 1.1 \\
10 & 19 & 1.1 & 4 & $(5)$ & 1.3 \\
20 & 15 & 2.0 & 4 & $(2)$ & 1.2 \\
30 & 18 & 3.6 & 3 & $(2)$ & 1.0 \\
40 & 22 & 5.8 & 4 & $(2)$ & 1.0 \\
50 & 25 & 9.4 & 10 & $(1)$ & 1.1 \\
\hline
\end{tabular}

Numbers in parenthesis were obtained by passing the flows through the buffer flasks after a round mixing flask and the others without the buffer flask after an elliptical mixing flask.

$\mathrm{C}_{\mathrm{obs}}$ : The time-averaged concentration observed in the stationary state.

Diffusion tube : $2.1 \mathrm{~mm}$ (i.d.), $162 \mathrm{~mm}$ (length)

Flow rate of air : $520 \mathrm{ml} / \mathrm{min}$ 


\section{PERFORMANCE OF DIFFUSION CELL}

Table 3. Relation between inner diameter of diffusion tube and the coefficient of variation of concentration and the ratio of the time-averaged concentration to the calculated one.

\begin{tabular}{c|c|c|cc|c}
\hline $\begin{array}{l}\text { Inner } \\
\text { diameter } \\
(\mathrm{mm})\end{array}$ & Length & $\begin{array}{l}\text { Calculated } \\
\text { concentration } \\
(\mathrm{ppm})\end{array}$ & $\begin{array}{l}\text { Coefficient } \\
\text { of variation } \\
(\%)\end{array}$ & $\begin{array}{c}\text { Ratio } \\
\mathrm{C}_{\text {obs }} / \mathrm{C}_{\text {calc }}\end{array}$ \\
\hline 0.7 & 166 & 0.4 & 73 & $(5)$ & 0.9 \\
1.1 & 159 & 1.0 & 18 & $(5)$ & 1.0 \\
2.1 & 162 & 3.6 & 3 & $(2)$ & 1.0 \\
3.7 & 164 & 12 & 1 & $(1)$ & 1.0 \\
5.7 & 169 & 26 & 1 & $(2)$ & 1.0 \\
7.3 & 168 & 43 & 1 & $(1)$ & 1.0 \\
9.9 & 161 & 82 & 1 & $(-)$ & 0.9 \\
\hline
\end{tabular}

Numbers in parenthesis were obtained by passing the flows through the buffer flasks after a round mixing flask and the others without the buffer flask after an elliptical mixing flask.

$\mathrm{C}_{\mathrm{obs}}$ : The time-avereged condentration observed in the stationary state.

Flow rate of air: $520 \mathrm{ml} / \mathrm{min}$

Temperature of water bath $: 30^{\circ} \mathrm{C}$

calculated one. Only temperature of the water bath was changed from $5^{\circ} \mathrm{C}$ to 50 ${ }^{\circ} \mathrm{C}$. The coefficients of variation increased with the difference between the temperature in the water bath and in the room. However, these greater coefficients did not accompany greater deviation of the time-averaged concentrations from the calculated ones in all ranges of the temperature applied.

Table 3 shows the effect of the inner diameter of the diffusion tube on the coefficient of variation of concentration and on the coincidence of the time-averaged concentration with the calculated one. Only the inner diameters of the tubes were changed from $0.7 \mathrm{~mm}$ to $9.9 \mathrm{~mm}$, while the length of the tube was fixed at about $16 \mathrm{~cm}$. The coefficients of variation were very small with the inner diameters of more than $2 \mathrm{~mm}$ but they increased conspicuously with the inner diameters less than $2 \mathrm{~mm}$. Inspite of this trend, the time-averaged concentrations were in fairly good agreement with the calculated ones in all ranges of the inner diameters used.

Table 4 shows the effect of length of the diffusion tube on the coefficient of

Table 4. Relation between length of diffusion tube and the coefficient of variation of concentration and the ratio of the time-averaged concentration to the calculated one.

\begin{tabular}{c|c|c|c}
\hline $\begin{array}{l}\text { Length } \\
(\mathrm{mm})\end{array}$ & $\begin{array}{l}\text { Calculated } \\
\text { concentration }(\mathrm{ppm})\end{array}$ & $\begin{array}{l}\text { Coefficient } \\
\text { of variation }(\%)\end{array}$ & $\begin{array}{l}\text { Ratio } \\
\mathrm{C}_{\mathrm{obs}} / \mathrm{C}_{\mathrm{calc}}\end{array}$ \\
\hline 102 & 43 & 2 & 1.0 \\
169 & 26 & 1 & 1.0 \\
205 & 21 & 1 & 1.0 \\
\hline
\end{tabular}

All the flows were not passed through the buffer flask after an elliptical mixing flask.

$\mathrm{C}_{\mathrm{obs}}$ : The time-averaged concentration observed in the stationary state

Inner diameter of diffusion tube : $5.7 \mathrm{~mm}$

Temperature of water bath : $520 \mathrm{ml} / \mathrm{min}$ 


\section{H. ARITO AND R. SODA}

variation of concentration and on the coincidence of the time-averaged concentration with the calculated one. Three diffusion tubes of length ranging from 10.2 $\mathrm{cm}$ to $20.5 \mathrm{~cm}$ were used, while the inner diameter was fixed at $5.7 \mathrm{~mm}$. The coefficients of variation were small and independent of length within the range of lengths of the tubes used. All the time-averaged concentrations were in fairly good agreement with the calculated ones.

Insight of Tables 1, 2, 3 and 4 shows that concentrations of the benzene vapor-air mixture ranging stepwise from $0.4 \mathrm{ppm}$ to $82 \mathrm{ppm}$ are obtainable with this simple diffusion cell under various conditions of the four factors and that almost all of their time-averaged concentrations are in good agreement with the calculated ones. This fact reveals that this cell serves conveniently for preparing a continuous flow of vapor-air mixture of the concentrations ranging widely from sub ppm to hundred ppm without further dilution of the mixture and also that the concentrations of the prepared flow can be predicted from both the flow rate of air and the calculated rate of diffusion of vapor as indicated in the equations 1 and 2 .

Much fluctuations in concentrations, however, were observed under certain ranges of the four factors, although these time-averaged concentrations are in good agreement with the calculated ones. This unfavorable phenomenon was found in high flow rate of air with small inner diameter of a diffusion tube (Table 1) and in a large difference in room and bath temperature (Table 2) and in small inner diameters of diffusion tubes (Table 3). It is considered that these ranges of the factors make the diffusion process of the vapor through a tube unstable, so that the concentrations become so fluctuating. High flow rates of air, low temperatures and small inner diameters of the tubes are required to prepare low concentrations of the mixture. Therefore, from the viewpoint of practical application of the diffusion cell, such unfavorable phenomenon should be taken into account for the preparation of a constant concentration in which these ranges of the factors are used.

In order to reduce much fluctuation of concentration which were found in these ranges, the three buffer flasks were set up as indicated in Fig. 1-B. The effect of the buffer flasks on decrease in the fluctuation are shown in the parenthesized numbers of Tables 1, 2 and 3. The buffer flasks could effectively smooth the considerably fluctuating concentrations which were prepared in the ranges of high flow rates of air, low and high temperatures and small inner diameters of the diffusion tubes. Except these ranges, almost constant concentrations can be obtained without setting the buffer flasks. When the vapor-air mixture is prepared by proper choice of the conditions which produce much fluctuation, it is necessary to set up the buffer flasks.

As the results of consideration of not only coincidence of the time-averaged concentration with the calculated one but also fluctuation in concentration, the simple diffusion cell serves extensively as a generator of a continuous flow of the organic vapor-air mixture of constant concentrations from sub ppm to hundred 


\section{PERFORMANCE OF DIFFUSION CELL}

ppm. The diffusion cell can be applied for studies such as experiments on inhalation of toxic vapors by animals, experiments on human olfactory perception to organic vapors, experiments on measurement of collection efficiency of vapors and so forth, where low and constant concentrations are required.

\section{REFERENCE}

1) Saltzman, B. E., (1961). Anal. Chem. 33, 1100.

2) Kusnetz, H. L., Saltzman, B. E. and Lanier, M. C., (1960). Amer. Ind. Hyg. Ass. J. $21,361$.

3) Cotabish, H. N., McConnaushey, P. W. and Messer, H. C., (1961). Amer. Ind. Hyg. Ass. J. 22, 392.

4) McKelvey, J. M. and Hoelscher, H. E., (1957). Anal. Chem. 29, 123.

5) Fortuin, J. M. H., (1956). Anal. Chim. Acta 15, 521.

6) Altshuller, A. P. and Cohen, I. R., (1960). Anal. Chem. 32, 802.

7) Campbell, E. E. and Ide, H. M., (1966). Amer. Ind. Hyg. Ass. J. 27, 323.

8) Nader, J. S., (1958). Amer. Ind. Hyg. Ass. J. 19, 1.

9) Turk, A., (1953). J. Agr. Food Chem. 4, 306.

10) International Critical Tables, Vol. 5, McGraw-Hill, New York, 1929. 